\title{
Short communication: Glucose infusion into early postpartum cows defines an upper physiological set point for blood glucose and causes rapid and reversible changes in blood hormones and metabolites
}

\author{
M. C. Lucy, ${ }^{1}$ R. C. Escalante, D. H. Keisler, W. R. Lamberson, and D. J. Mathew \\ Division of Animal Sciences, University of Missouri, Columbia 65211
}

\begin{abstract}
Low blood glucose concentrations after calving are associated with infertility in postpartum dairy cows perhaps because glucose is a master regulator of hormones and metabolites that control reproductive processes. The hypothesis was that low blood glucose postpartum is caused by inadequate glucose entry rate relative to whole-body demand as opposed to the alternative possibility that postpartum cows have a lower regulatory set point for blood glucose. Eight early postpartum (10 to 25 d) dairy cows ( 5 Holstein and 3 Guernsey) were jugular catheterized. During the first $24 \mathrm{~h}$, cows were infused with physiological saline at $83.3 \mathrm{~mL} / \mathrm{h}$. After $24 \mathrm{~h}$, the infusion solution was switched to $50 \%$ dextrose that was infused at a rate of $41.7 \mathrm{~mL} / \mathrm{h}$ (total daily glucose dose $=500 \mathrm{~g}$ ). On d 3 and $\mathrm{d} 4$, the rate of glucose infusion was increased to $83.3 \mathrm{~mL} / \mathrm{h}$ (daily dose $=1,000 \mathrm{~g}$ ) and $125 \mathrm{~mL} / \mathrm{h}$ (daily dose $=1,500 \mathrm{~g}$ ), respectively. On d 5, physiological saline was infused at $83.3 \mathrm{~mL} / \mathrm{h}$. Blood was sampled hourly through a second jugular catheter (contralateral side) and analyzed for glucose, nonesterified fatty acids, $\beta$-hydroxybutyrate, insulin-like growth factor 1 , and insulin. Blood glucose concentrations on d 1 (saline infusion) averaged $53.4 \pm$ $1.7 \mathrm{mg} / \mathrm{dL}$. Blood glucose concentrations increased on d 2 when cows were infused with $500 \mathrm{~g} / \mathrm{d}$ and increased further on $\mathrm{d} 3$ when cows were infused with $1,000 \mathrm{~g}$ of glucose/d. Increasing the infusion rate to $1,500 \mathrm{~g} / \mathrm{d}$ on d 4 did not cause a further increase in blood glucose concentrations. Based on a segmented regression analysis, the upper physiological set point for blood glucose was $72.1 \mathrm{mg} / \mathrm{dL}$. Both insulin and insulin-like growth factor 1 concentrations increased in response to glucose infusion and decreased when cows were infused with saline on d 5 . Serum nonesterified fatty acids and $\beta$-hydroxybutyrate concentrations decreased in response to glucose infusion and rebounded upward on d 5 (saline infusion). In conclusion, early postpar-
\end{abstract}

Received March 12, 2013.

Accepted May 15, 2013.

${ }^{1}$ Corresponding author: lucym@missouri.edu tum cows had circulating blood glucose concentrations that were well below the upper set point defined in this study $(72.1 \mathrm{mg} / \mathrm{dL})$. Infusing approximately 1,000 $\mathrm{g}$ of glucose daily increased blood glucose to the physiological set point and rapidly changed the hormonal and metabolic profile that typifies postpartum cows. The inability of the early postpartum cow to achieve an adequate entry rate for glucose relative to whole-body demand is a possible mechanism that links postpartum physiology and nutrition to reproduction in dairy cows. Key words: glucose, postpartum, set point, reproduction

\section{Short Communication}

Glucose is a critical nutrient in the postpartum dairy cow because glucose is used by the mammary gland for the synthesis of milk (Bell, 1995). Glucose is also required by a variety of other tissue types, including those involved in reproduction (Nishimoto et al., 2006; Clark et al., 2011; Berlinguer et al., 2012). Although glucose is a major product of carbohydrate digestion in the rumen, it is rapidly fermented to VFA that are then oxidized for energy in peripheral tissues. Dietary starch that escapes rumen fermentation is largely metabolized within visceral tissue and most studies have shown no net gain in terms of glucose reaching the general circulation via the portal vein (Nocek and Tamminga, 1991). Based on the assumptions that $72 \mathrm{~g}$ of glucose are required for each kilogram of milk produced (Bell, 1995) and that most of the glucose arising from postruminal starch digestion is metabolized within visceral tissue (Nocek and Tamminga, 1991), several kilograms of glucose daily must be produced de novo by hepatic gluconeogenesis for a cow in peak production. The cow can only meet $85 \%$ of her glucose requirement during early lactation, leaving an estimated 500-g daily deficit for glucose (Bell, 1995).

Low blood glucose in early lactation may be a causative mechanism for infertility in dairy cows. In a recent study by Green et al. (2012), for example, cows that became pregnant after first AI had greater blood glucose concentrations early postpartum (within 
$30 \mathrm{~d}$ after calving) compared with cows that did not become pregnant. We found a similar relationship in a second study where blood glucose concentrations on d 3 after calving were associated with the probability of pregnancy later postpartum (Garverick et al., 2013). To better understand the relationship between postpartum glucose and reproduction, we wanted to determine the upper physiological set point (Cabanac, 2006) for blood glucose in an early postpartum cow. If the set point is approximately equal to circulating blood glucose concentrations, then lesser blood glucose concentrations in cows that do not become pregnant may be explained mechanistically by a low physiological set point for blood glucose. If the set point is well above the circulating concentrations, then lesser blood glucose in cows that do not become pregnant may be explained by inadequate blood glucose entry rate (predominately determined by liver gluconeogenic capacity; Aschenbach et al., 2010) relative to exit rate (predominately determined by milk produced; Bell, 1995). To examine this question, we infused a daily dose of glucose (500 to 1,500 g) that approximated the calculated deficiency for glucose in the postpartum cow (Bell, 1995). We then examined the defended set point for blood glucose concentration. We also examined the response of metabolic hormones and metabolites to the blood glucose infusion.

Eight early postpartum dairy cows [5 Holstein (10, 15, 21, 22, and $25 \mathrm{~d}$ postpartum and 3 Guernsey (12, 15, and $16 \mathrm{~d}$ postpartum)] were selected and acclimated to tie-stalls (removed from the freestall and placed in the tie-stalls in the afternoons) for approximately $1 \mathrm{wk}$ before the start of the trial. The cows were deemed clinically normal for rectal temperature, uterine discharge, respiration rate, rumen fill, and urinary ketone concentrations according to standard operating procedures established by the University of Missouri College of Veterinary Medicine (Columbia). The trial was conducted in 2 replicates in May and June 2012. On the first day, cows were milked at approximately $0900 \mathrm{~h}$ and then the left and right jugular veins were catheterized by using $14 \mathrm{~g} \times 13-\mathrm{cm}$ catheters (MILACATH, extended use; Mila International Inc., Erlanger, KY). The catheters were sutured to the skin to hold in place. One catheter was used for blood collection and the second catheter was used for infusion. The blood collection catheter was fitted with a microbore set extension $(48 \mathrm{~cm}, 0.5-\mathrm{mL}$ priming volume; Braun Medical Inc., Bethlehem, PA) and the entire apparatus was flushed with heparinized saline solution [50 US Pharmacopeia (USP) units/ $\mathrm{mL}]$, capped, and secured to the halter. The infusion catheter was fitted with a large bore extension set $(76$ $\mathrm{cm}, 4.3-\mathrm{mL}$ priming volume; Braun Medical Inc.) that was also flushed with heparinized saline, capped, and secured. The cows were then placed in a tie-stall where they remained for the entire trial.

At approximately noon on the first day, the infusion line was connected to a Plum XL infusion pump (Abbott Laboratories, Abbott Park, IL) with a Primary I.V. PlumSet (Hospira Inc., Lake Forest, IL; $264 \mathrm{~cm}$, 19-mL priming volume) and a large-bore coiled extension set (International Win Ltd., Kennett Square, PA). The coiled extension set enabled the cow to freely stand or lay down during the infusion. During the first 24 $\mathrm{h}$, cows were infused with physiological saline $(0.9 \%$ sodium chloride; Abbott Laboratories, North Chicago, IL) at $83.3 \mathrm{~mL} / \mathrm{h}$. After $24 \mathrm{~h}$ (noon on $\mathrm{d} 2$ ) the infusion solution was switched to $50 \%$ dextrose (Agri Laboratories Ltd., St. Joseph, MO), which was infused at a rate of $41.7 \mathrm{~mL} / \mathrm{h}(1,000 \mathrm{~mL} / \mathrm{d}$; total daily glucose dose $=500 \mathrm{~g})$. At noon on $\mathrm{d} 3$ and 4 , the rate of glucose infusion was increased to $83.3 \mathrm{~mL} / \mathrm{h}(2,000 \mathrm{~mL} / \mathrm{d}$; total daily glucose dose $=1,000 \mathrm{~g})$ and $125 \mathrm{~mL} / \mathrm{h}(3,000$ $\mathrm{mL} / \mathrm{d}$; total daily glucose dose $=1,500 \mathrm{~g}$ ), respectively. On d 5, physiological saline was infused at $83.3 \mathrm{~mL} / \mathrm{h}$.

Blood was sampled hourly through the second catheter (positioned in the contralateral jugular vein relative to glucose infusion catheter). The blood was collected into 9-mL Monovette Z tubes (Sarstedt Inc., Newton, NC). The blood glucose concentration was tested immediately by using a ReliOn Ultima blood glucose meter (Abbott Diabetes Care Inc., Alameda, CA). The blood was then placed at $4^{\circ} \mathrm{C}$ where it was allowed to clot for approximately $4 \mathrm{~h}$. Serum was collected by centrifugation of whole blood $(1,500 \times g$ for $15 \mathrm{~min})$ and then stored at $-20^{\circ} \mathrm{C}$ in polypropylene tubes until analyzed for hormone and metabolite concentrations. The serum NEFA and BHBA concentrations were measured hourly by using the Wako NEFA-HR(2) kit (Wako Diagnostics, Richmond, VA) and the BHBA reagent set (Pointe Scientific Inc., Canton MI), respectively. An RIA was used to determine the serum concentrations of IGF1 (Rhoads et al., 2008) in the hourly samples. Serum insulin concentrations were measured daily at midnight, 0400 h, 0800 h, 1200 h, 1600 h, and 2000 h by using a bovine insulin ELISA (Alpco Diagnostics, Salem, NH).

Cows remained in the tie-stall for the entire trial and were milked twice daily (0500 and $1700 \mathrm{~h}$ ) by using a portable milker. Milk was weighed after each milking. Cows were fed a TMR that was $47.0 \%$ DM with 1.58 Mcal of $\mathrm{NE}_{\mathrm{L}} / \mathrm{kg}$ of $\mathrm{DM}$ and composed of (\% of diet DM) corn silage (32.3), alfalfa haylage (8.6), alfalfa hay (7.5), brewer's grains (4.8), soybean meal (4.1), soy hulls (5.9), dry corn (19.4), SoyPLUS (West Central Cooperative, Ralston, IA; 5.0), and concentrate/ mineral/vitamin premix (12.1\%). The concentrate/ mineral/vitamin premix contained (\%) fine corn meal 
(43.7), blood meal (11.3), Energy Booster (Hubbard Feeds, Mankato, MN; 14.3), limestone (7.7), sodium bicarbonate (5.9), potassium carbonate (3.7), Dynamate (Mosaic Co., Plymouth, MN; 2.5), $\mathrm{NaCl}$ (2.2), magnesium oxide (2.0), Diamond V XP (Diamond V, Cedar Rapids, IA; 2.2), trace mineral mix (calcium carbonate, manganous oxide, copper sulfate, zinc oxide, cobalt carbonate, calcium iodate, ferrous sulfate, and sodium selenite; 1.7), vitamin $\mathrm{E}(9,091 \mathrm{IU} / \mathrm{kg} ; 1.2)$, vitamin A, D, E premix (1,818,182 IU of vitamin A per $\mathrm{kg}, 363,636$ IU of vitamin $\mathrm{D}_{3}$ per $\mathrm{kg}, 545 \mathrm{IU}$ of vitamin $\mathrm{E}$ per $\mathrm{kg}$; 0.47), Smartamine (Adisseo, Alpharetta, GA; 1.4), and Rumensin 90 (Elanco Animal Health, Greenfield, IN; $0.06)$. The TMR was balanced to meet or exceed NRC (2001) requirements and included (\% of DM) $48.53 \%$ forage, $16.34 \% \mathrm{CP}, 22.45 \% \mathrm{ADF}, 34.14 \% \mathrm{NDF}, 35.90 \%$ NFC, $24.24 \%$ starch, and $5.84 \%$ ether extract. Cows were fed following orts collection at $1500 \mathrm{~h}$ daily. Feed bunks were replenished with fresh feed if the cow consumed the feed that was offered. Feed was turned and pushed in front of the cow approximately once an hour. The DMI was calculated daily based on the weight of feed offered minus orts. Cows were weighed at the beginning and the end of the trial.

Blood concentrations of glucose and serum concentrations of NEFA, BHBA, and IGF1 were analyzed with a repeated measures design by using a mixed models procedure (PROC MIXED, SAS version 9.3; SAS Institute Inc., Cary, NC). Cow nested within breed was included in the model as a random effect. Time ( 0 to $120 \mathrm{~h}$ ) was included in the model as a repeated variable. Covariance structures \{compound symmetry (CS), heterogeneous CS (CSH), autoregressive (AR), and heterogeneous $\mathrm{AR}(1)[\mathrm{ARH}(1)]$, among others\} were tested and the most appropriate structure (based on the lowest Akaike information criterion, corrected Akaike information criterion, and Bayesian information criterion values) was used for each analysis (Littell et al., 1998). A second series of mixed-models analyses were completed, which included the effect of breed, day, and time. In these analyses, time was defined as the hours after the start of infusion at noon each day (1 to $24 \mathrm{~h}$ ). Cow nested within breed was included in the model as a random effect and time was included in the model as a repeated variable. The PDIFF procedure in PROC MIXED of SAS was used as a means separation procedure to examine differences between days. A goodness-of-fit test (Kaps and Lamberson, 2009) was used to determine if blood concentrations of glucose and serum concentration of NEFA, BHBA, and IGF1 responded linearly to infusion of glucose. The preliminary analyses suggested that blood glucose reached a plateau. A segmented regression analysis fitting a model of 2 simple linear functions joined at a knot was conducted using PROC NLIN in SAS (Kaps and Lamberson, 2009) to determine the physiological set point for blood glucose and the infusion dose required for cows to reach the set point. The value of infused glucose at the knot represents the infusion dose required for cows to reach the set point, and the corresponding point on the vertical axis is the physiological set point for blood glucose. Means are reported as least squares means \pm standard error of the mean, unless stated otherwise. Statistical significance was declared at $P \leq 0.05$. Statistical tendency was defined as $0.05<P \leq 0.10$.

Blood glucose concentrations on d 1 (saline infusion) averaged $53.4 \pm 1.7 \mathrm{mg} / \mathrm{dL}$ and did not differ between Holstein and Guernsey cows (Figure 1A). Blood glucose concentrations increased $(P<0.001)$ on $\mathrm{d} 2$ when cows were infused with $500 \mathrm{~g} / \mathrm{d}$ and increased further $(P<0.001)$ on $\mathrm{d} 3$ when cows were infused with 1,000 $g$ of glucose/d (Table 1). Increasing the infusion rate to $1,500 \mathrm{~g} / \mathrm{d}$ on $\mathrm{d} 4 \mathrm{did}$ not cause a further increase in blood glucose concentrations $(P=0.25)$. When saline was infused again on d 5, blood glucose concentrations decreased rapidly and were approximately equal to the d-1 concentration within $4 \mathrm{~h}$. Based on a segmented regression analysis, the upper physiological set point for blood glucose was $72.1 \mathrm{mg} / \mathrm{dL}$. This set point was approximately $20 \mathrm{mg} / \mathrm{dL}$ above blood glucose concentrations of saline-infused cows on d 1 or 5 .

The upper physiological set point for glucose that we observed $(72.1 \mathrm{mg} / \mathrm{dL})$ was well above the circulating glucose concentrations during saline infusion and greater than the glucose concentration typically found in early postpartum cows. Blood glucose entry rate (predominately determined by gluconeogenic rate; Aschenbach et al., 2010) relative to the rate of glucose utilization, therefore, does not enable the cow to approach the upper physiological set point. The amount of glucose that was required to reach the upper physiological set point was predicted to be $1,021 \mathrm{~g} / \mathrm{d}$. The value of $1,021 \mathrm{~g} / \mathrm{d}$ is the output of PROC NLIN (SAS) and represents the value where the segmented regression lines cross (i.e., the knot). Every single cow in this study had a significant increase $(P<0.05)$ in blood glucose when the infusion was increased from 500 to 1,000 $\mathrm{g} / \mathrm{d}$ but increasing the dose rate from 1,000 to 1,500 $\mathrm{g} / \mathrm{d}$ did not increase blood glucose in 7 of 8 cows. The set point that we observed in this study $(72.1 \mathrm{mg} / \mathrm{dL}$ or $4.0 \mathrm{mmol} / \mathrm{L}$ ) is approximately equal to the blood glucose concentration observed in studies of late-lactation cows (Chelikani et al., 2003; Bradford and Allen, 2007). These same studies included early lactation cows with blood glucose concentrations approximately equal to saline-infused cows in this study. Late-lactation cows, 

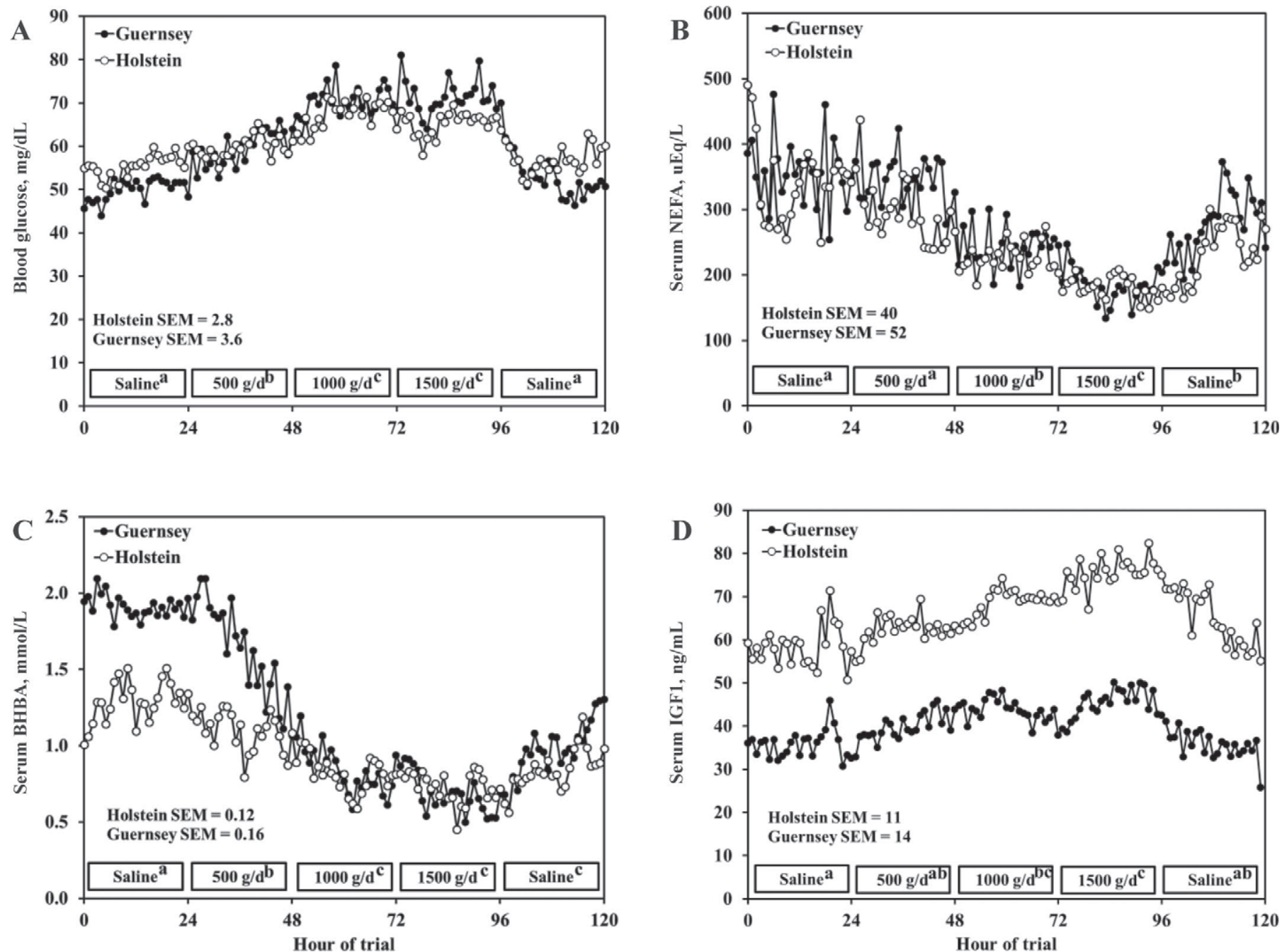

Figure 1. Concentrations of glucose (A), NEFA (B), BHBA (C), and IGF1 (D) in blood samples collected once every hour from early postpartum Holstein $(\mathrm{n}=5)$ or Guernsey $(\mathrm{n}=3)$ dairy cows that were infused with either saline $(\mathrm{d} 1,0$ to $24 \mathrm{~h}), 500 \mathrm{~g}$ of glucose/d $(\mathrm{d} 2,24$ to 48 h), 1,000 g of glucose/d (d 3, 48 to $72 \mathrm{~h}$ ), 1,500 g of glucose/d (d 4, 72 to $96 \mathrm{~h}$ ), or saline (d 5, 96 to 120 h). Days with different superscripts $(\mathrm{a}-\mathrm{c})$ differ at $P<0.05$ (PDIFF procedure of PROC MIXED; SAS Institute Inc., Cary, NC).

therefore, seem to have blood glucose concentrations near their physiological set point perhaps because glucose entry rate is greater or milk production is less.

With respect to our original question, we conclude that the postpartum cow does not have a lesser physiological set point for blood glucose (i.e., the cow is not defending a low blood glucose concentration). When we infused glucose at rates that were approximately equal to the calculated deficiency for glucose in postpartum dairy cows (Bell, 1995), we were able to define an upper physiological limit of $72.1 \mathrm{mg} / \mathrm{dL}$. The aforementioned associations that we have found between blood glucose and reproduction (Green et al., 2012; Garverick et al., 2013), therefore, may be explained by inadequate glucose entry rate relative to the exit rate for glucose. We assert that the lesser blood glucose may affect the processes through which ovarian activity is restored via glucose itself or glucose-mediated actions on circulating concentrations of insulin, IGF1, and (or) lipid metabolites.

A rapid decrease $(P<0.001)$ was observed in both NEFA (Figure 1B) and BHBA (Figure 1C) concentrations in response to glucose infusion. Both NEFA and BHBA concentrations increased when glucose infusion was stopped and saline was infused on $\mathrm{d} 5$. The decrease in NEFA and BHBA concentrations in response to glucose infusion is known to occur, as demonstrated in studies where glucose was administered as a bolus intravenous infusion (Roche et al., 2008; Wagner and Schimek, 2010), a continuous infusion (Léonard and Block, 1997; Al-Trad et al., 2009), or as an abomasal infusion (Lemosquet et al., 1997; Larsen and Kris- 
Table 1. Least squares means and SEM for daily milk production, DMI, and serum concentrations of hormones and metabolites for Holstein $(\mathrm{n}=5)$ and Guernsey $(\mathrm{n}=3)$ cows that were infused with saline $(\mathrm{d} 1), 500 \mathrm{~g}$ of glucose/d (d 2), 1,000 g of glucose/d (d 3), 1,500 g of glucose/d (d 4), or saline (d 5)

\begin{tabular}{|c|c|c|c|c|c|c|c|}
\hline \multirow[b]{2}{*}{ Item } & \multicolumn{5}{|c|}{ Treatment $^{1}$} & \multirow[b]{2}{*}{ SEM } & \multirow[b]{2}{*}{$P$-value ${ }^{2}$} \\
\hline & Saline & $500 \mathrm{~g} / \mathrm{d}$ & $1,000 \mathrm{~g} / \mathrm{d}$ & $1,500 \mathrm{~g} / \mathrm{d}$ & Saline & & \\
\hline Milk, $\mathrm{kg} / \mathrm{d}$ & $35.2^{\mathrm{a}}$ & $36.1^{\mathrm{a}}$ & $37.0^{\mathrm{a}}$ & $35.4^{\mathrm{a}}$ & $32.6^{\mathrm{b}}$ & 1.4 & $<0.01$ \\
\hline DMI, kg/d & 15.0 & 14.2 & 13.1 & 13.7 & 12.7 & 0.9 & NS \\
\hline DMI, $\%$ of BW & 2.7 & 2.6 & 2.4 & 2.5 & 2.3 & 0.1 & NS \\
\hline Glucose, $\mathrm{mg} / \mathrm{dL}$ & $53.4^{\mathrm{a}}$ & $59.8^{\mathrm{b}}$ & $68.7^{\mathrm{c}}$ & $67.7^{\mathrm{c}}$ & $55.3^{\mathrm{a}}$ & 1.7 & $<0.001$ \\
\hline NEFA, $\mu \mathrm{Eq} / \mathrm{L}$ & $348.1^{\mathrm{a}}$ & $314.8^{\mathrm{a}}$ & $232.8^{\mathrm{b}}$ & $182.3^{\mathrm{c}}$ & $250.2^{\mathrm{b}}$ & 20.7 & $<0.001$ \\
\hline $\mathrm{BHBA}, \mathrm{mmol} / \mathrm{L}$ & $1.52^{\mathrm{a}}$ & $1.29^{\mathrm{b}}$ & $0.83^{\mathrm{c}}$ & $0.71^{\mathrm{c}}$ & $0.89^{\mathrm{c}}$ & 0.10 & $<0.001$ \\
\hline $\mathrm{IGF} 1, \mathrm{ng} / \mathrm{mL}$ & $49.9^{\mathrm{a}}$ & $54.0^{\mathrm{ab}}$ & $59.2^{\mathrm{bc}}$ & $64.4^{\mathrm{c}}$ & $53.9^{\mathrm{ab}}$ & 3.5 & $<0.01$ \\
\hline Insulin, ng/mL & $0.31^{\mathrm{a}}$ & $0.34^{\mathrm{ab}}$ & $0.35^{\mathrm{b}}$ & $0.37^{\mathrm{bc}}$ & $0.32^{\mathrm{ab}}$ & 0.02 & $<0.01$ \\
\hline
\end{tabular}

${ }^{\mathrm{a}-\mathrm{c}}$ Means within a row with different superscript letters differ at $P<0.05$ (PDIFF procedure of PROC MIXED; SAS Institute Inc., Cary, NC).

${ }^{1}$ Data are LSM with pooled SEM for the LSM. The hormone and metabolite concentrations are the LSM for all samples collected on a given day.

${ }^{2} P$-value for the effect of day.

tensen, 2009). This may be the first study to report hourly sampling for NEFA and BHBA in response to a non-bolus glucose infusion designed to recapitulate a physiologically relevant glucose entry rate in early postpartum cows.

A linear increase was observed in insulin concentration during the glucose infusion (Table $1 ; P<0.05$ ) and this result agrees with previous work (Roche et al., 2008; Al-Trad et al., 2009; Wagner and Schimek, 2010). Although the postpartum cow is less sensitive to insulin compared with the nonlactating cow (Hayirli, 2006), the data presented herein provide evidence that the cow is able to defend an upper physiological set point via insulin release. Insulin decreases circulating NEFA concentration through its capacity to stimulate lipogenesis and inhibit lipolysis in adipose tissue (Hayirli, 2006). Insulin also has antiketogenic properties because it increases peripheral ketone utilization and decreases hepatic ketone production (Hayirli, 2006). The possibility also exists of a direct effect of the infused glucose on FA metabolism via the glucose-FA cycle (Hue and Taegtmeyer, 2009). This latter mechanism would function independently of insulin.

An important observation from this study was the rapid, linear, and reversible increase in circulating IGF1 that occurred in response to glucose infusion (Figure 1D; $P<0.001$ ). Relative to d 1 (saline infusion), the IGF1 concentration did not increase when $500 \mathrm{~g}$ of glucose/d was infused on d 2 (Table 1). Increasing the glucose infusion rate to $1,000 \mathrm{~g} / \mathrm{d}$ on $\mathrm{d} 3$, however, increased IGF1 concentrations compared with d $1(P<0.01)$. The greatest IGF1 concentrations were found when cows were infused with 1,500 g of glucose/d (d 4). The IGF1 concentrations decreased rapidly when saline was infused on d 5, with cows returning to their initial IGF1 concentrations by the end of the saline infusion (Figure 1D). Rutter et al. (1989) also observed a rapid and reversible increase in serum IGF1 when approximately $500 \mathrm{~g}$ of glucose was infused daily into postpartum beef cows over a 6 -d period and serum was sampled once daily. Léonard and Block (1997) concluded that insulin mediated the stimulatory effects of glucose on postpartum IGF1 through its capacity to recouple the somatotropic axis. Our results are consistent with the conclusions of Léonard and Block (1997) because both insulin and IGF1 concentrations progressed upwards in response to glucose infusion and decreased when cows were infused with saline on d 5 (Table 1). The recoupling mechanism is believed to involve insulin stimulation of growth hormone receptor (GHR) 1A and IGF1 expression in liver (Butler et al., 2003). Future work should examine hepatic GHR and IGF1 expression in response to physiologically relevant doses of glucose.

Blood IGF1 concentrations are an important consideration for postpartum reproduction (Lucy 2011; Kawashima et al., 2012). The magnitude of the IGF1 increase that we observed in this study (10 to $15 \mathrm{ng} / \mathrm{mL}$ increase when 1,500 g of glucose/d was infused; Figure 1D; Table 1) approximates the magnitude of IGF1 difference reported elsewhere for cycling versus noncycling cows (Beam and Butler, 1998) or postpartum pregnant versus nonpregnant cows (Taylor et al., 2004; Green et al., 2012). The release of insulin and IGF1 in response to glucose may act on the hypothalamus and pituitary to stimulate the secretion of gonadotropins (Adam et al., 2000) or may act on ovarian tissue by having a synergistic effect with gonadotropins (Kwintkiewicz and Giudice, 2009). In addition to affecting the restoration of ovarian activity, early postpartum insulin and IGF1 may affect uterine health through their effects on 
the uterine cells themselves or immune cells that are essential to uterine involution (Sunahara et al., 2012; Himpe et al., 2013). The concentrations of BHBA and NEFA were also affected by glucose and both metabolites have potential effects on reproduction (Leroy et al., 2008; Van Hoeck et al., 2011) and immune function (Grinberg et al., 2008; Ster et al., 2012).

This experiment was not designed to test metabolic or hormonal difference between Guernsey or Holstein breeds or animal productivity in response to glucose infusion. A decrease $(P<0.05)$ was observed in milk production on d 5 when cows were switched from glucose to saline infusion (Table 1). The DMI was not affected by treatment (Table 1) but cows did have lesser BW on $\mathrm{d} 5$ relative to the start of the trial $(562 \pm 20$ vs. $536 \pm 20 \mathrm{~kg}$ for d 1 vs. $\mathrm{d} 5 ; P<0.05)$. Milk production $(32.1 \pm 2.1$ and $38.5 \pm 1.5 \mathrm{~kg} / \mathrm{d} ; P<0.05)$ and DMI $(12.4 \pm 0.9$ and $15.1 \pm 0.7 \mathrm{~kg} / \mathrm{d} ; P<0.05)$ were less for Guernsey compared with Holstein cows but BW and DMI expressed as a percentage of BW did not differ between Guernsey and Holstein cows. The breed-by-day interactions for milk production, DMI, BW, and DMI expressed as a percentage of BW were not significant. A breed-by-day interaction was observed for glucose $(P$ $<0.001$; Figure 1A), NEFA $(P<0.05$; Figure 1B), BHBA (Figure 1C; $P<0.001$ ), and IGF1 (Figure 1D; $P<0.001$ ). The breed-by-day interaction for insulin was not significant. The magnitude of the difference between Holstein and Guernsey cows appeared to be greatest for BHBA and IGF1 (Figures 1C and 1D). When individual cows were examined, we found that BHBA concentrations for each of the 3 Guernsey cows were greater than the Holstein cows on d 1 (saline). For IGF1, 4 of 5 Holstein cows had greater IGF1 concentrations compared with the Guernsey cows. The BHBA and IGF1 differences may be explained by the fact that the Guernsey cows were, on average, $4 \mathrm{~d}$ earlier postpartum. Inherent differences also may exist between the breeds with respect to circulating hormones and metabolites during the early postpartum period.

In conclusion, postpartum cows defended an upper physiological set point of $72.1 \mathrm{mg} / \mathrm{dL}$ for blood glucose concentration. This concentration was well above the typical circulating glucose concentration for a postpartum cow. The upper set point was predicted at 1,021 $\mathrm{g} / \mathrm{d}$ of infused glucose. Glucose infusion increased insulin and IGF1 concentrations, and decreased NEFA and BHBA concentrations. The magnitude of the increase in IGF1 concentration after glucose infusion was approximately equal to that observed in associative studies linking greater IGF1 concentration with improved reproduction in postpartum cows. The inability of the early postpartum cow to achieve an adequate entry rate for glucose relative to her glucose requirement is a pos- sible mechanism that links postpartum physiology and nutrition to reproduction in postpartum dairy cows.

\section{REFERENCES}

Adam, C. L., T. S. Gadd, P. A. Findlay, and D. C. Wathes. 2000. IGF-I stimulation of luteinizing hormone secretion, IGF-binding proteins (IGFBPs) and expression of mRNAs for IGFs, IGF receptors and IGFBPs in the ovine pituitary gland. J. Endocrinol. $166: 247-254$.

Al-Trad, B., K. Reisberg, T. Wittek, G. B. Penner, A. Alkaassem, G. Gäbel, M. Fürll, and J. R. Aschenbach. 2009. Increasing intravenous infusions of glucose improve body condition but not lactation performance in midlactation dairy cows. J. Dairy Sci. 92:5645-5658.

Aschenbach, J. R., N. B. Kristensen, S. S. Donkin, H. M. Hammon, and G. B. Penner. 2010. Gluconeogenesis in dairy cows: The secret of making sweet milk from sour dough. IUBMB Life 62:869-877.

Beam, S. W., and W. R. Butler. 1998. Energy balance, metabolic hormones, and early postpartum follicular development in dairy cows fed prilled lipid. J. Dairy Sci. 81:121-131.

Bell, A. W. 1995. Regulation of organic nutrient metabolism during transition from late pregnancy to early lactation. J. Anim. Sci. 73:2804-2819.

Berlinguer, F., A. Gonzalez-Bulnes, I. Contreras-Solis, A. Spezzigu, L. Torres-Rovira, S. Succu, S. Naitana, and G. G. Leoni. 2012. Glucogenic supply increases oocyte developmental competence in sheep. Reprod. Fertil. Dev. 24:1055-1062.

Bradford, B. J., and M. S. Allen. 2007. Phlorizin induces lipolysis and alters meal patterns in both early- and late-lactation dairy cows. J. Dairy Sci. 90:1810-1815.

Butler, S. T., A. L. Marr, S. H. Pelton, R. P. Radcliff, M. C. Lucy, and W. R. Butler. 2003. Insulin restores hepatic growth hormone (GH) responsiveness during lactation-induced negative energy balance in dairy cattle: Effects on expression of insulin-like growth factor-I and GH receptor 1A. J. Endocrinol. 176:205-217.

Cabanac, M. 2006. Adjustable set point: To honor Harold T. Hammel. J. Appl. Physiol. 100:1338-1346.

Chelikani, P. K., D. H. Keisler, and J. J. Kennelly. 2003. Response of plasma leptin concentration to jugular infusion of glucose or lipid is dependent on the stage of lactation of Holstein cows. J. Nutr. 133:4163-4171.

Clark, A. R., Y. M. Stokes, and J. G. Thompson. 2011. Estimation of glucose uptake by ovarian follicular cells. Ann. Biomed. Eng. $39: 2654-2667$.

Garverick, H. A., M. N. Harris, R. Vogel-Bluel, J. D. Sampson, J. Bader, W. R. Lamberson, J. N. Spain, M. C. Lucy, and R. S. Youngquist. 2013. Concentrations of nonesterified fatty acids and glucose in blood of periparturient dairy cows are indicative of pregnancy success at first insemination. J. Dairy Sci. 96:181-188.

Green, J. C., J. P. Meyer, A. M. Williams, E. M. Newsom, D. H. Keisler, and M. C. Lucy. 2012. Pregnancy development from day 28 to 42 of gestation in postpartum Holstein cows that were either milked (lactating) or not milked (not lactating) after calving. Reproduction 143:699-711.

Grinberg, N., S. Elazar, I. Rosenshine, and N. Y. Shpigel. 2008 $\beta$-Hydroxybutyrate abrogates formation of bovine neutrophil extracellular traps and bactericidal activity against mammary pathogenic Escherichia coli. Infect. Immun. 76:2802-2807.

Hayirli, A. 2006. The role of exogenous insulin in the complex of hepatic lipidosis and ketosis associated with insulin resistance phenomenon in postpartum dairy cattle. Vet. Res. Commun. 30:749-774.

Himpe, E., S. A. Abdul Rahim, P. Verdood, H. Mano, and R. Kooijman. 2013. Tec kinase stimulates cell survival in transfected Hek293T cells and is regulated by the anti-apoptotic growth factor IGF-I in human neutrophils. Cell. Signal. 25:666-673.

Hue, L., and H. Taegtmeyer. 2009. The Randle cycle revisited: A new head for an old hat. Am. J. Physiol. Endocrinol. Metab. 297:E578-E591.

Kaps, M., and W. Lamberson. 2009. Biostatistics for Animal Science. 2nd ed. CABI Publishing, Cambridge, MA. 
Kawashima, C., M. Matsui, T. Shimizu, K. Kida, and A. Miyamoto. 2012. Nutritional factors that regulate ovulation of the dominant follicle during the first follicular wave postpartum in high-producing dairy cows. J. Reprod. Dev. 58:10-16.

Kwintkiewicz, J., and L. C. Giudice. 2009. The interplay of insulin-like growth factors, gonadotropins, and endocrine disruptors in ovarian follicular development and function. Semin. Reprod. Med. $27: 43-51$

Larsen, M., and N. B. Kristensen. 2009. Effect of abomasal glucose infusion on splanchnic and whole-body glucose metabolism in periparturient dairy cows. J. Dairy Sci. 92:1071-1083.

Lemosquet, S., N. Rideau, H. Rulquin, P. Faverdin, J. Simon, and R. Verite. 1997. Effects of a duodenal glucose infusion on the relationship between plasma concentrations of glucose and insulin in dairy cows. J. Dairy Sci. 80:2854-2865.

Léonard, M., and E. Block. 1997. Effects on nutrient and hormonal profile of long-term infusions of glucose or insulin plus glucose in cows treated with recombinant bovine somatotropin before peak milk yield. J. Dairy Sci. 80:127-143.

Leroy, J. L. M. R., G. Opsomer, A. Van Soom, I. G. F. Goovaerts, and P. E. J. Bols. 2008. Reduced fertility in high-yielding dairy cows: Are the oocyte and embryo in danger? Part II. Mechanisms linking nutrition and reduced oocyte and embryo quality in high high-yielding dairy cows. Reprod. Domest. Anim. 43:623-632.

Littell, R. C., P. R. Henry, and C. B. Ammerman. 1998. Statistical analysis of repeated measures data using SAS procedures. J. Anim. Sci. 76:1216-1231.

Lucy, M. C. 2011. Growth hormone regulation of follicular growth. Reprod. Fertil. Dev. 24:19-28.

NRC. 2001. Nutrient Requirements of Dairy Cattle. 7th rev. ed. Natl. Acad. Sci., Washington, DC.

Nishimoto, H., R. Matsutani, S. Yamamoto, T. Takahashi, K. G. Hayashi, A. Miyamoto, S. Hamano, and M. Tetsuka. 2006. Gene expression of glucose transporter (GLUT) 1, 3 and 4 in bovine follicle and corpus luteum. J. Endocrinol. 188:111-119.
Nocek, J. E., and S. Tamminga. 1991. Site of digestion of starch in the gastrointestinal tract of dairy cows and its effect on milk yield and composition. J. Dairy Sci. 74:3598-3629.

Rhoads, M. L., J. P. Meyer, W. R. Lamberson, D. H. Keisler, and M. C. Lucy. 2008. Uterine and hepatic gene expression in relation to days postpartum, estrus, and pregnancy in postpartum dairy cows. J. Dairy Sci. 91:140-150.

Roche, J. R., A. J. Sheahan, L. M. Chagas, and R. C. Boston. 2008. Short communication: Change in plasma ghrelin in dairy cows following an intravenous glucose challenge. J. Dairy Sci. 91:10051010.

Rutter, L. M., R. Snopek, and J. G. Manns. 1989. Serum concentrations of IGF-I in postpartum beef cows. J. Anim. Sci. 67:20602066.

Ster, C., M.-C. Loiselle, and P. Lacasse. 2012. Effect of postcalving serum nonesterified fatty acids concentration on the functionality of bovine immune cells. J. Dairy Sci. 95:708-717.

Sunahara, K. K., P. Sannomiya, and J. O. Martins. 2012. Briefs on insulin and innate immune response. Cell. Physiol. Biochem. 29:1-8.

Taylor, V. J., Z. Cheng, P. G. A. Pushpakumara, D. E. Beever, and D. C. Wathes. 2004. Relationships between the plasma concentrations of insulin-like growth factor-I in dairy cows and their fertility and milk yield. Vet. Rec. 155:583-588.

Van Hoeck, V., R. G. Sturmey, P. Bermejo-Alvarez, D. Rizos, A. Gutierrez-Adan, H. J. Leese, P. E. J. Bols, and J. L. M. R. Leroy. 2011. Elevated non-esterified fatty acid concentrations during bovine oocyte maturation compromise early embryo physiology. PLoS ONE 6:e23183.

Wagner, S. A., and D. E. Schimek. 2010. Evaluation of the effect of bolus administration of $50 \%$ dextrose solution on measures of electrolyte and energy balance in postpartum dairy cows. Am. J. Vet. Res. 71:1074-1080. 